\title{
Allocation of resources for health care in COVID-19 pandemic times: integrative review
}

\author{
Alocação de recursos para assistência à saúde em tempos da pandemia de COVID-19: revisão integrativa
}

Asignación de recursos para asistencia a la salud en tiempos de la pandemia de Covid-19: revisión integrativa

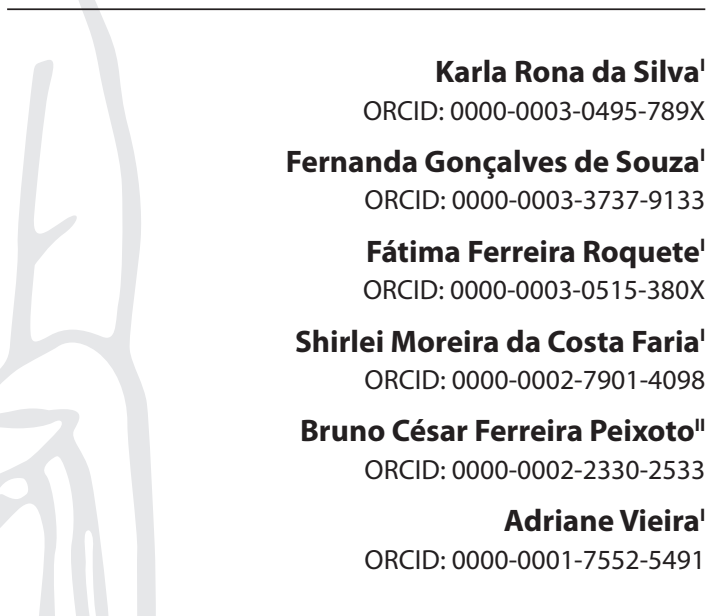

'Universidade Federal de Minas Gerais. Belo Horizonte, Minas Gerais, Brazil.

"Secretaria de Estado de Justiça e Segurança Pública de Minas Gerais, Diretoria de Apoio Logístico. Belo Horizonte, Minas Gerais, Brazil.

How to cite this article:

Silva KR, Souza FG, Roquete FF, Faria SMC Peixoto BCF, Vieira A. Allocation of resources for health care in COVID-19 pandemic times: integrative review. Rev Bras Enferm. 2020;73(Suppl 2):e20200244. doi: http://dx.doi.org/10.1590/0034-7167-2020-0244

\section{Corresponding author:}

Karla Rona da Silva

E-mail: karlarona0801@gmail.com

EDITOR IN CHIEF: Dulce Barbosa ASSOCIATE EDITOR: Alexandre Balsanelli

Submission: $04-03-2020$

Approval: 07-18-2020

\section{ABSTRACT}

Objective: To analyze information on resource allocation in the context of the COVID-19 pandemic, published in indexed scientific journals, from December 2019 to March 2020. Methods: This is an integrative literature review, which took place in March 2020. All databases were investigated and studies were found only in MEDLINE. After applying the established criteria, six articles were selected. Results: It was evident that the allocation of resources is carried out as the demands emerge. The fragility in presenting scientific-methodological evidence that can quide decision makers for assertive allocation of available resources is highlighted. The results showed that studies on this subject are incipient and need to be expanded. Final considerations: The need for health organizations and area authorities to be better prepared for the proper use of available resources, with allocation based on scientific evidence and maximization of resources is indicated.

Descriptors: Resource Allocation; Coronavirus; Pandemics; Delivery of Health Care; Health Services.

\section{RESUMO}

Objetivo: Analisar as informações sobre a alocação de recursos no contexto da pandemia de COVID-19, publicadas em periódicos científicos indexados, no período de dezembro de 2019 a março de 2020. Métodos: Trata-se de revisão integrativa da literatura, realizada em março de 2020. Foram investigadas todas as bases de dados e encontrados estudos somente na MEDLINE. Após a aplicação dos critérios estabelecidos, foram selecionados seis artigos. Resultados: Evidenciou-se que a alocação de recursos é realizada conforme emergem as demandas. Destaca-se a fragilidade na apresentação de evidência científico-metodológica que possa nortear os tomadores de decisão para alocação assertiva dos recursos disponíveis. Os resultados demonstraram que estudos sobre essa temática são incipientes e necessitam ser ampliados. Considerações finais: Indica-se a necessidade de as organizações de saúde e as autoridades da área estarem mais bem preparadas para o uso adequado dos recursos disponíveis, com a alocação baseada em evidências científicas e maximização dos recursos. Descritores: Alocação de Recursos; Coronavírus; Pandemias; Assistência à Saúde; Serviços de Saúde.

\section{RESUMEN}

Objetivo: Analizar las informaciones sobre la asignación de recursos en el contexto de la pandemia de COVID-19, publicadas en periódicos científicos indexados, en el período de diciembre de 2019 a marzo de 2020. Métodos: Se trata de revisión integrativa de la literatura, realizada en marzo de 2020. Han sido investigadas todas las bases de datos y encontrados estudios solamente en la MEDLINE. Después de la aplicación de los criterios establecidos, han sido seleccionados seis artículos. Resultados: Se evidenció que la asignación de recursos es realizada conforme emergen las demandas. Se destaca la fragilidad en la presentación de evidencia científico-metodológica que pueda orientar los tomadores de decisión para asignación asertiva de los recursos disponibles. Los resultados demostraron que estudios sobre esa temática son incipientes y necesitan ser ampliados. Consideraciones finales: Se indica la necesidad de las organizaciones de salud y las autoridades del área estar más bien preparadas para el uso adecuado de los recursos disponibles, con la asignación basada en evidencias científicas y maximización de los recursos.

Descriptores: Asignación de Recursos; Coronavirus; Pandemias; Asistencia a la Salud; Servicios de Salud. 


\section{INTRODUCTION}

The allocation of resources in the health field is an issue in evidence that deserves the expansion of discussions and the constant training of professionals for assertive decision making, with maximum certainty about the adequacy of investments. Thus, reasoned criteria need to be used for the best possible distribution of resources, taking into account the specificities of each country and therefore the regional, demographic and epidemiological differences of its population ${ }^{(1)}$. In this sense, the appropriate allocation of resources is desirable, especially in situations of pandemics, such as that of COVID-19 in 2020.

The situation caused by the coronavirus is officially treated by the World Health Organization (WHO) as a worldwide pandemic. Its infectious agent was first discovered in humans and isolated in 1937, having been described as "coronavirus" in 1965, after microscopic analysis. The new coronavirus was discovered on December 31, 2019 and received the technical name of SARSCoV-2. The first cases were registered in Wuhan, China ${ }^{(2-4)}$.

According to data on affected individuals, recorded in a WHO report, $81 \%$ refer to illnesses considered mild and uncomplicated, $14 \%$ evolve to a hospitalization requiring oxygen therapy and 5\% progress to severe situations requiring treatment in the Intensive Care Unit (ICU), with implantation of assisted ventilation/mechanical ventilation device. For these complications, the elderly and those affected by chronic diseases are considered risk groups ${ }^{(3)}$.

COVID-19 behaves as a highly contagious disease with fast spread. In cases of hospitalization, the care must be carried out in the shortest time and with the least displacement possible. Thus, it is necessary to allocate the best available resource, aiming at minimizing damage ${ }^{(3-5)}$. Some measures to contain the spread of the COVID-19 pandemic have been encouraged, such as: social isolation avoiding crowds; hygienization of hands with water and soap, whenever possible; avoid hugs, kissing and shaking hands; cough and sneeze etiquette; distance of 2 meters between people (3-4) $^{(3)}$

Strategies for reducing disease progression are essential, but optimizing and properly allocating resources for patient treatment and support are also of significant relevance. In Brazil, there is an almost permanent shortage of resources in the health area, which makes it essential to make assertive decisions in order to increase the necessary actions. In pandemic situations, the phenomenon worsens, which can be an element that increases the risk of a collapse of the health system ${ }^{(1-2,6-7)}$.

Therefore, it is considered pertinent and relevant to investigate what information has been published about resource allocation in the COVID-19 pandemic scenario. The research focus was the allocation of physical, material, pharmacological, human and financial resources. This research is justified for elucidating, in the face of the COVID-19 pandemic, which actions have been developed and discussed in the scientific environment about the allocation of resources. The results offer potential contribution to the discussions and decision-making of health professionals and researchers in the field. For the scientific community, the study is relevant because the subject is emerging and worldwide in scope, therefore with the ability to fill important gaps in the literature.

\section{OBJECTIVE}

To analyze the information on resource allocation in the context of the COVID 19 pandemic, published in indexed scientific journals, from December 2019 to March 2020.

\section{METHODS}

It is an integrative review of the literature, a method that gathers and synthesizes the knowledge produced through the analysis of the results evidenced in primary studies. For the development of this review, the Ganong theoretical reference was adopted, and the following steps were contemplated: a) selection of the research question; b) sampling; c) representation of the characteristics of the research; d) analysis of the selected studies; e) analysis and interpretation of the results and report of the review ${ }^{(8)}$. The study was guided by the following question: What information was published in indexed scientific journals, from December 2019 to March 2020, on resource allocation in the context of the COVID-19 pandemic?

Inclusion criteria were defined as: complete articles and technical notes, published in national and international indexed scientific journals addressing the topic "Resource allocation in the context of the COVID-19 pandemic", in Portuguese, English and Spanish, from December 2019 to March 2020, which could be localized through the descriptors registered in the Health Sciences Descriptors portal (DeCS), which are Resource Allocation; Coronavirus; Pandemics; Health Care; Health Services. The search strategy used enabled the words "coronavirus" and "resource allocation" to always be among the descriptors, in whose crossover the Boolean operator AND was used. The established time cut is justified because it is a milestone of the global COVID-19 pandemic. The exclusion criteria used were: studies that treated COVID-19 with an exclusive focus on epidemiological data, contagion, symptoms and/or clinical complications; other articles that did not address the research topic or did not answer the guiding question; and duplicate publications.

The selection process is represented in Figure 1. It is worth noting that all existing health care databases were consulted; however, only in the Medical Literature Analysis and Retrieval System Online (MEDLINE) database were articles located that met the established inclusion criteria. A Technical Note was also part of this review, due to its relevance for understanding the issue in question. The selection process followed the PRISMA guidelines and recommendations for identification, selection, eligibility and inclusion.

After selecting the studies, a careful reading of the title and, later, of the summary of each publication was carried out, with the objective of verifying the consonance with the guiding question of the research. When doubts occurred regarding the inclusion or exclusion of any article, it was read in its entirety in order to reduce possible losses of publications relevant to the research. Data collection took place in the second half of March 2020. A synoptic table (Chart 1) has been developed using Microsoft Office Word 2010 to organize the data and make the analysis possible.

In accordance with the ethical aspects of this comprehensive review, authors of the studies were assured that all were adequately referenced. 


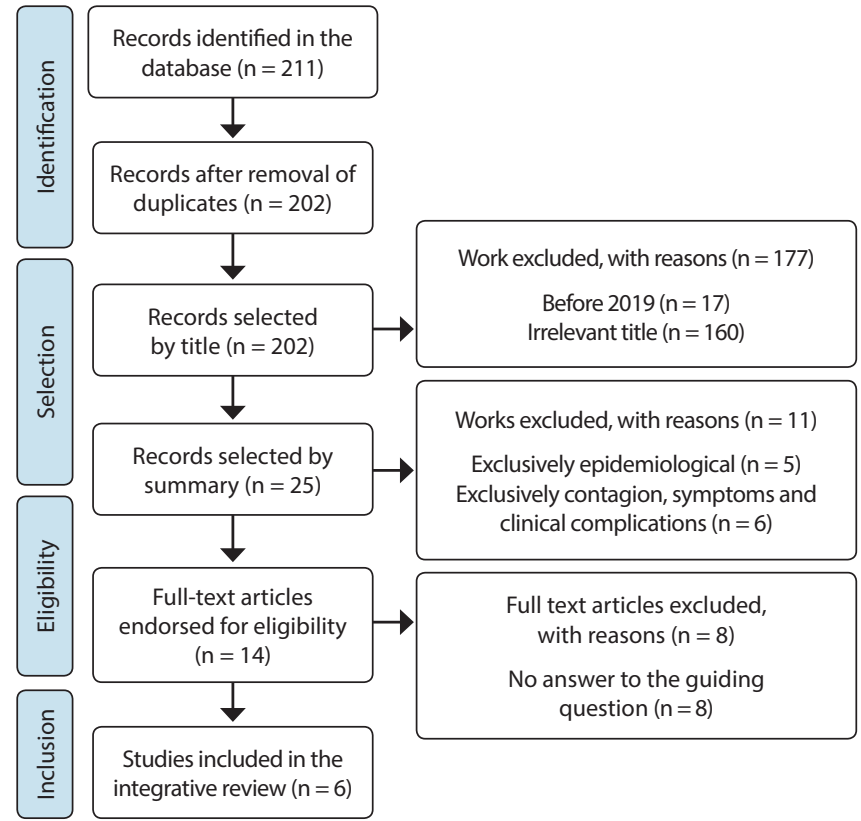

Figure 1 - Flowchart of the systematization of the search for studies for integrative literature review, 2020

\section{RESULTS}

In this study, six articles were analyzed that met the established inclusion and exclusion criteria. The final selection is presented in Chart 1, second title, year and country of publication, delineation, objective and outcomes, and the publications are presented in alphabetical order, by title.
As for the studies that make up this integrative review, all come from online journals and renowned scientific institutes: Institutes - MedRxiv ${ }^{(9)}$, Imperial College London ${ }^{(10)}$; Journals - The New England Journal of Medicine ${ }^{(2)}$, The Lancet Respiratory Medicine ${ }^{(11)}$, Health Security ${ }^{(12)}$ and NAM Perspectives ${ }^{(6)}$. The Technical Note ${ }^{(5)}$ is a selected study that was chosen through a manual search on the site of the Center for Regional Development and Planning (CEDEPLAR), of the Federal University of Minas Gerais, and is relevant because it provides elements for the discussions of this research. Regarding the design of the selected studies, the use of descriptive and quantitative research and the predominance of publications from the United States stand out. No studies similar to the one proposed in this scientific research were found.

It should be noted that all selected articles refer comprehensively to material and physical resources, especially mechanical fans, general and ICU beds respectively. No manuscripts were found that make a specific and in-depth analysis of human, financial and pharmacological resource allocation in the context of the COVID-19 pandemic. In some studies ${ }^{(9-10)}$, however, the provision of human resources, as an element to be considered, is mentioned briefly.

The main outcomes refer to: uncertainties regarding the suppression or mitigation of the propagation of COVID-19 and the risks of large demands for health services ${ }^{(9)}$; the need to develop measures for decision-making with regard to the allocation of resources ${ }^{(6)}$; recommendations to consider ethical values in the face of resource scarcity ${ }^{(2)}$; stratification of interventions ${ }^{(10)}$; planning and managing the shortage of resources to control the pandemic ${ }^{(11)}$; global collaboration and adaptive capacity in pandemic scenarios ${ }^{(12)}$.

Chart 1 - Summary of studies analyzed by title, year and country of publication, design, objective and outcomes, 2020

\begin{tabular}{|c|c|c|c|c|}
\hline Title & $\begin{array}{c}\text { Year/ } \\
\text { Country }\end{array}$ & Design & Objective & Outcomes \\
\hline $\begin{array}{l}\text { COVID-19 health care } \\
\text { demand and mortality } \\
\text { in Sweden in response } \\
\text { to non-pharmaceutical } \\
\text { (NPIs) mitigation and } \\
\text { suppression scenarios }\end{array}$ & $\begin{array}{l}2020 \\
\text { USA }\end{array}$ & $\begin{array}{l}\text { Descriptive } \\
\text { and } \\
\text { quatitative } \\
\text { study }\end{array}$ & $\begin{array}{l}\text { To estimate the impact of COVID-19 } \\
\text { on the Swedish population, } \\
\text { considering the demography and } \\
\text { human mobility of the municipalities, } \\
\text { in mitigation and suppression } \\
\text { scenarios, taking into account: } \\
\text { incidence schedules, hospitalization } \\
\text { rates, intensive care unit (ICU) need } \\
\text { and mortality in relation to the } \\
\text { current ICU capacity and care costs. }\end{array}$ & $\begin{array}{l}\text { Scenarios where contact rates and social distance are } \\
\text { reduced by } 50 \% \text { result in mitigation. For suppression } \\
\text { it would be necessary to reduce by } 75 \% \text {. The need for } \\
\text { ICU for the total population in Sweden varies from } 6 \text { to } \\
30 \text { times the ICU capacity at the peak of the outbreak, } \\
\text { in the scenario where only isolation and quarantine are } \\
\text { practiced. At a time when contact rates and social distance } \\
\text { are very strong, the outbreak is suppressed but risks } \\
\text { recovering when social distance stops. The results indicate } \\
\text { that in scenarios with less strong reductions in contact } \\
\text { and social distance rates increase the risks of large hospital } \\
\text { and intensive care demands. }\end{array}$ \\
\hline $\begin{array}{l}\text { Duty to Plan: Health } \\
\text { Care, Crisis Standards } \\
\text { of Care, and Novel } \\
\text { Coronavirus SARS- } \\
\text { CoV- } 2^{(6)}\end{array}$ & $\begin{array}{l}2020 \\
\text { USA }\end{array}$ & $\begin{array}{l}\text { Qualitative } \\
\text { study }\end{array}$ & $\begin{array}{l}\text { Discuss the application of Crisis } \\
\text { Standards of Care (CSC) principles } \\
\text { to clinical care, including personal } \\
\text { protective equipment (PPE), } \\
\text { intensive care, and outpatient and } \\
\text { emergency challenges posed by } \\
\text { coronavirus or other major epidemic } \\
\text { or pandemic events. }\end{array}$ & $\begin{array}{l}\text { The principles of crisis standards of care (CSC) are: } \\
\text { justice; duty to care; duty to manage resources; } \\
\text { transparency; consistency; proportionality; } \\
\text { accountability. Strategies to consider when } \\
\text { addressing a resource shortage situation are: } \\
\text { anticipating challenges, developing plans, storing } \\
\text { materials; implementing shortages supply } \\
\text { conservation strategies; providing a drug or } \\
\text { equivalent or near equivalent delivery device; } \\
\text { adapting the use of equipment for alternative } \\
\text { purposes (e.g., anesthesia machine as a ventilator); } \\
\text { reusing a wide variety of materials after proper } \\
\text { disinfection or sterilization; removing a resource from } \\
\text { one area/patient and allocating it to another with } \\
\text { greater likelihood of benefit. }\end{array}$ \\
\hline
\end{tabular}




\begin{tabular}{|c|c|c|c|c|}
\hline Title & $\begin{array}{c}\text { Year/ } \\
\text { Country }\end{array}$ & Design & Objective & Outcomes \\
\hline $\begin{array}{l}\text { Fair Allocation of Scarce } \\
\text { Medical Resources in the } \\
\text { Time of COVID-19(2) }\end{array}$ & $\begin{array}{l}2020 \\
\text { USA }\end{array}$ & $\begin{array}{l}\text { Descriptive } \\
\text { and } \\
\text { quantitative } \\
\text { study }\end{array}$ & $\begin{array}{l}\text { Analyze how medical resources can } \\
\text { be fairly allocated during a COVID-19 } \\
\text { pandemic. }\end{array}$ & $\begin{array}{l}\text { Ethical values - maximizing benefits, treating equally, } \\
\text { promoting and rewarding instrumental value and } \\
\text { giving priority to the poorest - produce six specific } \\
\text { recommendations for allocating medical resources } \\
\text { during the COVID-19 pandemic: maximize benefits; } \\
\text { prioritize health professionals; do not allocate on a } \\
\text { first-come, first-served basis; be sensitive to evidence; } \\
\text { recognize research participation; and apply the same } \\
\text { principles to all patients with or without COVID-19. }\end{array}$ \\
\hline $\begin{array}{l}\text { Impact of non- } \\
\text { pharmaceutical } \\
\text { interventions (NPIs) } \\
\text { to reduce COVID-19 } \\
\text { mortality and } \\
\text { healthcare demand }\end{array}$ & $\begin{array}{c}2020 \\
\text { United } \\
\text { Kingdom }\end{array}$ & $\begin{array}{l}\text { Descriptive } \\
\text { and } \\
\text { quantitative } \\
\text { study }\end{array}$ & $\begin{array}{l}\text { Show the impact of non- } \\
\text { pharmaceutical interventions (NPIs) } \\
\text { to reduce COVID } 19 \text { mortality and } \\
\text { demand for health care. }\end{array}$ & $\begin{array}{l}\text { The results show that multiple interventions will need } \\
\text { to be stratified, regardless of whether suppression or } \\
\text { mitigation is the overarching policy objective. However, } \\
\text { suppression will require the stratification of more intense } \\
\text { and socially disruptive measures than mitigation. The } \\
\text { choice of interventions ultimately depends on the } \\
\text { relative feasibility of their implementation and their likely } \\
\text { effectiveness in different social contexts. }\end{array}$ \\
\hline $\begin{array}{l}\text { Planning and provision } \\
\text { of ECMO services for } \\
\text { severe ARDS during the } \\
\text { COVID-19 pandemic } \\
\text { and other outbreaks of } \\
\text { emerging infectious } \\
\text { diseases }^{(11)}\end{array}$ & $\begin{array}{c}2020 \\
\text { United } \\
\text { Kingdom }\end{array}$ & $\begin{array}{c}\text { Qualitative } \\
\text { study }\end{array}$ & $\begin{array}{l}\text { Discuss and analyze health service } \\
\text { planning and delivery regarding the } \\
\text { use of extracorporeal membrane } \\
\text { oxygenation (ECMO) for the } \\
\text { treatment of patients with acute } \\
\text { respiratory distress syndrome (ARDS) } \\
\text { related to coronary heart disease } \\
2019 \text { (COVID-19) and the application } \\
\text { in other emerging infectious disease } \\
\text { outbreaks. }\end{array}$ & $\begin{array}{l}\text { The intensive care response should be part of a larger } \\
\text { pandemic control plan to reduce transmission and } \\
\text { prevent deaths. In addition, much needs to be done } \\
\text { through global collaboration to contain the disease } \\
\text { and prioritize vaccine production to change the } \\
\text { pathogen's natural history. Real-time data collection and } \\
\text { sharing, establishing global biobanks and promoting } \\
\text { an international culture of collaborative research that } \\
\text { removes geographic boundaries, are crucial to rapidly } \\
\text { identify at-risk populations, patients who benefit from } \\
\text { therapies such as ECMO and possible therapeutic targets. }\end{array}$ \\
\hline $\begin{array}{l}\text { Strategies to Inform } \\
\text { Allocation of Stockpiled } \\
\text { Ventilators to } \\
\text { Healthcare Facilities } \\
\text { During a Pandemic } \\
\text { (12) }\end{array}$ & $\begin{array}{l}2020 \\
\text { USA }\end{array}$ & $\begin{array}{c}\text { Qualitative } \\
\text { study }\end{array}$ & $\begin{array}{l}\text { Determine the need for and } \\
\text { allocation of fans during a public } \\
\text { health emergency, focusing on } \\
\text { strategies to help state and local } \\
\text { planners allocate fans stored in } \\
\text { health facilities during a pandemic } \\
\text { by responding to critical factors in } \\
\text { the facility. }\end{array}$ & $\begin{array}{l}\text { Using ethical principles to assess need, determine capacity } \\
\text { to absorb additional fans, and ensure resources for the } \\
\text { most vulnerable populations, state and local public health } \\
\text { authorities can equitably allocate fans stored during a } \\
\text { pandemic. Having early strategies for allocating scarce } \\
\text { resources, such as fans, can improve decision making, with } \\
\text { the understanding that plans will have to adapt to the } \\
\text { realities presented during a response to the pandemic. }\end{array}$ \\
\hline
\end{tabular}

\section{DISCUSSION}

In a context of uncertainties related to the spread and duration of the COVID 19 pandemic, a serious threat to the health system and, consequently, to supply chains with regard to medicines and materials used for the care and assistance of affected users is evident ${ }^{(2,7)}$. In addition, there is also a weakening in the quantity of human resources available to meet population demands. This phenomenon is worrying, since the disease is serious enough to overload from health care to infrastructure, as highlighted by all researchers in the studies analyzed ${ }^{(9-10)}$.

The investigations that make up this review clearly show that the final course and impact of COVID-19 are uncertain, but that the disease has great potential to collapse health systems by compromising the supply of human resources, support, sanitation and other inputs essential to the proper functioning of health services in response to the pandemic $c^{(2,6,9-10)}$.

In this sense, it is possible to infer the need to create strategies to mitigate the phenomenon in the short term; and, in the long term, to eliminate it. Short-term strategies have been implemented in several countries, such as: reinforcement of hygiene practices; social isolation; and special attention to the elderly and those with chronic diseases. These are important elements, but the effectiveness of any single intervention is likely to be limited, requiring multiple interventions to be combined to achieve a substantial impact in reducing transmission of SARS-CoV-2. Thus, researchers indicate that actions need to be implemented quickly, decisively, and collectively ${ }^{(5,7)}$

The diversity in the population's health conditions and the fact that the health system presents differences in contexts of low and high per capita income promote different impacts in terms of mortality estimates and demands for medical assistance. Thus, the effect of the disease becomes more severe in low-income settings where the capacity to provide services is more limited ${ }^{(2,6)}$. Understanding the subject in his economic aspect in pandemic scenarios is relevant, however this understanding cannot be dissociated from the physical, social, cultural and emotional aspects, since this junction is the first step towards a singular care that values its completeness with equity ${ }^{(13)}$.

The Technical Note, included in this review, analyzes the demand and supply of general hospital beds, ICUs and assisted ventilation equipment in Brazil due to the COVID 19 pandemic, taking into account microregional impacts. It considers the demand generated by the COVID-19 pandemic in a developing country at intervals of 1 to 6 months. The results showed that the main problems would begin to emerge when the rate of infection caused by SARS-CoV- 2 reached $1 \%$ of the population for general beds. In addition, it is understood that the impact 
on the capacity of care will depend on the time horizon of this infection, considering public and private health services. For Intensive Care beds and mechanical ventilation support, the tendency would be to overload several health micro-regions in the country, which is especially serious for the reality of the rapid spread of SARS-CoV-2(5).

At this juncture, it is indicated that decision makers and those responsible for resource allocation make use of simulations to plan the referencing of resources needed for service: for example, the allocation of mechanical ventilation equipment ${ }^{(5)}$. In addition, it is worth mentioning the relevance of simulation to disseminate and stimulate adherence to guidelines with a view to minimizing dissemination; understand the overall capacity of the system; and, subsequently, provide elements for discussions that can support the formulation of specific health policies for this pandemic.

Another aspect evidenced in the studies was the non-referencing of theoretical basis on resource allocation. Only one publication cited the principles of the Crisis Standards of Care (CSC), an instrument initially developed for medical professionals and decision makers, which aims to ensure fair processes for making clinically informed decisions about the allocation of scarce resources during an epidemic. These principles were structured by the US Institute of Medicine in 2009 and guided the development of strategies to better prepare, conserve, replace, adapt, reuse and reallocate resources. However, it should be noted that the authors themselves question whether these principles are reasonable and ethical for pandemic situations, especially for COVID-19(6).

Studies indicate that decision making for resource allocation is somewhat conflicting and health professionals do not always feel prepared to do it ${ }^{(1,6)}$. Pandemic events require serenity, teamwork and technical-scientific preparation of professionals in order to optimize the use of existing resources, which are generally scarce ${ }^{(11)}$. In this context, it is necessary to elaborate a careful planning, which enables the careful allocation of equipment and the training of personnel, in order to provide quality care to the population ${ }^{(12)}$.

The need to allocate inputs, equipment, beds, drugs and human resources in pandemic situations can generate ethical and moral conflicts for decision makers, resulting in physical and/or mental illness ${ }^{(1)}$. Decision-making can be understood as a process permeated by ethical deliberations involving individualized selection of people. Moreover, the management processes, the organizational culture, the lack of understanding on the part of professionals about the scope of their actions, the feelings of powerlessness, the lack of empowerment and the discomfort in professional practice interfere in decision making ${ }^{(7)}$. In this way, ongoing capacity building, improvements in the management process and health monitoring of professional decision-makers emerge as a relevant reflection and agenda point in discussions on health decision-making, especially in pandemic situations.

Studies have addressed the social and economic costs of the measures to be adopted, signaling the urgent need to mitigate transmission and thus decrease the rate of growth of this pandemic. Furthermore, researchers indicate that it is necessary to reduce the height of the epidemic peak and the peak demand in health services, as well as to slow down the total number of infected people ${ }^{(2,5)}$. If this does not occur, there will be a severe demand for resources and, consequently, the need to ration equipment and interventions, which may compromise the entire care, increasing the risks of complications and the mortality rate of the population ${ }^{(3,6)}$.

With regard to the allocation of material resources in the COVID 19 pandemic scenario, it was possible to evidence that the scientific discussion is anchored in the mitigation or suppression of the pandemic, from the adoption of several public health measures, listed by authorities on the subject, with the need for broad social adherence ${ }^{(2,6)}$. However, researchers point out that there are many uncertainties, with a need for constant investment in scientific research, public policy and robust health systems to elucidate and implement the best possible intervention strategies s,9-10). $^{(5)}$

The fragility to make decisions about the best equipment allocation ratifies the unpreparedness of professionals when allocating resources, since this decision should not be anchored in pandemic control measures, but in pre-established criteria, which would allow the allocation of the best available resource to meet a given population reality ${ }^{(11-12)}$. As guidelines for the definition of these criteria ${ }^{(1,7,12)}$, previous analyses suggest the use of bioethics principles, which are: beneficence; non-maleficence; autonomy; and justice ${ }^{(14)}$.

There are challenges to be overcome in the field of resource allocation, especially in determining sound criteria and strategies for this activity, given that during the pandemic, decision-making needs to be rapid and assertive ${ }^{(11)}$. Some authors propose strategies for the allocation of mechanical ventilation equipment during a pandemic, stating that public health authorities need to be prepared for the abrupt increase in demand for care, that is, they need to identify and consult health services about their capacity to care and the possibility of expanding them, before the phenomenon sets $\mathrm{in}^{(12)}$.

It is essential that an inventory of the quantity of human resources, equipment, medicines and inputs for the service be carried out beforehand, because nobody is prepared for a pandemic. The infrastructure also needs to be evaluated, especially in view of the possibility of absorbing additional resources ${ }^{(11-15)}$.

The study conducted by Emanuel et al. (2020) presented six specific recommendations to allocate medical resources in the COVID-19 pandemic, which are worth highlighting: maximize benefits; prioritize health professionals; do not allocate on a first-come, first-served basis; be sensitive to evidence; recognize research participation; apply the same principles to all patients ${ }^{(2)}$.

Thus, based on the material analyzed in this review, scientific evidence is elucidated that signals the urgent need to develop proactive strategies with solid intervention plans consistent with the reality experienced in each country, respecting the particularities of the target population. This positioning aims to optimize the use of resources in the event of a worsening of the current global scenario, which may contribute to intensify the demands for the various health resources.

\section{Study limitations}

In the literature, there was a significant scarcity of research on the subject under analysis, which strengthens the relevance of this study. However, as a limitation, the fact that searches were performed in Health area databases, a particular interest of the investigation, without contemplating sources from the Administration, in general, and from the Public Administration, in particular, can be raised. This choice of researchers was based on the need to 
know the subject in the light of public health management, since it is a specificity of the pandemic scenario. The great majority of the findings on the general theme of COVID-19, in the period analyzed, refer, however, to epidemiological aspects, statistical modeling, therapeutic possibilities, symptoms and mitigation behaviors, which do not contemplate the relevant particularity, traced in this review, that is, the allocation of resources in the COVID-19 scenario.

\section{Contributions to Health and Public Policy}

The results of this integrative review may help health care professionals, especially those in decision-making roles, to reflect on the importance of best practices in resource allocation in the face of the COVID-19 pandemic. For academia, the findings show the need to expand research in the field of management and public health policies, especially with regard to ethical, financial and cost aspects, with a view to contributing elements to better decisions for those who need to make difficult choices on resource allocation in pandemic scenarios.

\section{FINAL CONSIDERATIONS}

The critical analysis of the articles in this review has shown that resource allocation in pandemic contexts, such as COVID-19, is done as demands arise. The studies point out several weaknesses in the sphere of resource availability, such as: low quantity of human resources, general beds, ICU beds and assisted ventilation equipment, besides the theoretical and methodological basis for such actions being fragile and incipient. As for the establishment of criteria for assertive allocation, it is notorious that there are no universal criteria based on other similar experiences to support the actions. This gap can be justified by the circumstances created by the COVID-19 pandemic, that is, an unknown conjuncture, permeated by uncertainties and conflicting information, impregnated by moral, political, social and economic dilemmas.

Thus, the results described here point to the need for health organizations, managers, care professionals and authorities in the area to be better prepared for the proper use of available resources, with allocation based on scientific evidence and maximization of scarce resources. In this way, potential individual, systemic and social damage in the global sense can be mitigated.

Some issues have emerged from this integrative review: How to use a cost system as a tool for resource allocation? How can limited resources be more fairly allocated in pandemic scenarios? Who are the professionals prepared to make decisions in the face of the current scarcity of resources that underlie this phenomenon? What knowledge, skills and behaviors are needed by those who make decisions about resource allocation in pandemic scenarios? Given the global dimension of this pandemic, what are the best practices for allocation of scarce resources described in the literature?

These and other questions remain open, suggesting that there is still much to be known on this subject. Future studies are essential to contribute to the empowerment of decision-makers in the assertive allocation of health resources, as well as to build and disseminate comprehensive response strategies to this disease.

\section{FUNDING}

Dean of Research (PRPq) of the Federal University of Minas Gerais - UFMG.

\section{REFERENCES}

1. Silva KR, Ribeiro RM, Roquete FF, Rodrigues CM, Lopes PT, Fernandes ML, et al. Narratives of health professionals relating to scarce resources in an urgency service. Int J Adv Engin Res Sci. 2019;6(6):66-73. doi: 10.22161/ijaers.6.6.7

2. Emanuel EJ, Persad G, Upshur R, Thome B, Parker M, Glickman A, et al. Fair allocation of scarce medical resources in the time of Covid-19. N Engl J Med. 2020;1(3):1-7. doi: 10.1056/NEJMsb2005114

3. World Health Organization (WHO). Coronavirus disease 2019 (COVID-19): situation report - 51 [Internet]. 2020 [cited 2020 Mar 30]. Available from: https://www.who.int/emergencies/diseases/novel-coronavirus-2019/situation-reports

4. Li Q, Guan X, Wu P. Early transmission dynamics in Wuhan, China, of novel coronavirus-infected pneumonia. N Engl J Med. 2020;38(2):1199207. doi: $10.1056 /$ NEJMoa2001316

5. Noronha K, Guedes GR, Turra CM, Andrade MV, Botega L, Nogueira D, et al. Análise de demanda e oferta de leitos hospitalares gerais, UTI e equipamentos de ventilação assistida no Brasil em função da pandemia do Covid-19: impactos microrregionais ponderados pelos diferenciais de estrutura etária, perfil etário de infecção e risco etário de internação [Internet]. Nota técnica. Belo Horizonte; 2020. [cited 2020 Mar 30]. Available from: https://www.cedeplar.ufmg.br/noticias/1223-nota-tecnica-analise-de-demanda-e-oferta-de-leitoshospitalares-gerais-uti-e-equipamentos-de-ventilacao-assistida-no-brasil-em-funcao-da-pandemia-do-covid-19

6. Hick JL, Hanfling D, Wynia MK, Pavia AT. 2020. Duty to Plan: Health Care, Crisis Standards of Care, and Novel Coronavirus SARS-CoV-2 discussion paper. NAM Perspectives. 2020;5(3):1-13. doi: 10.31478/202003b

7. Faria SMC, Martins SM, Rodrigues CM, Roquete FT, Silva KR. Prioritization of patients in the microalocative area: reflectionson academic training andethics. Braz J Health Rev[Internet]. 2019 [cited 2020 Mar 30];2(2):1953-67. Availlable from: http://www.brjd.com.br/index.php/ BJHR/article/view/1531/1458

8. Ganong LH. Integrative reviews of nursing research. Res Nurs Health [Internet]. 2007 [cited 2020 Mar 1];10(1):1-11. Available from: https:// www.ncbi.nlm.nih.gov/pubmed/3644366

9. Sjödin H, Johansson AF, Farooq Z, Brännström A, Kriit HK, Wilder-Smith A, et al. Covid-19 health care demand and mortality in Sweden in response to nonpharmaceutical (NPIs) mitigation and suppression scenarios. medRxiv. 2020;23(3):1-15. doi: 10.1101/2020.03.20.20039594 
10. Ferguson NM, Laydon D, Nedjati-Gilani G. Impact of non-pharmaceutical interventions (NPIs) to reduce Covid-19 mortality and healthcare demand. London: Imperial College London; 2020;16(3):1-20. doi: 10.25561/77482

11. Ramanathan K, Antognini D, Combes A, Paden M, Zakhary B, Ogino M, et al. Planning and provision of ECMO services for severe ARDS during the COVID-19 pandemic and other outbreaks of emerging infectious diseases. Lancet Respir Med. 2020;20(3):1-9. doi: 10.1016/ S2213-2600(20)30121-1

12. Koonin LM, Pillai S, Kahn EB, Moulia D, Patel A. Strategies to inform allocation of stockpiled ventilators to healthcare facilities during a pandemic. Health Security. 2020;18(2):1-6. doi: 10.1089/hs.2020.0028

13. Silva Al, Loccioni MFL, Orlandini RF, Rodrigues J, Peres GM, Maftum MA. Projeto Terapêutico Singular para profissionais da Estratégia de Saúde da Família. Cogitare Enferm. 2016;21(3):1-8. doi: 10.5380/ce.v21i3.45437

14. Beauchamp TL, Childress JF. Princípios de Ética Biomédica. São Paulo: Loyola; 2002. 574 p.

15. Zaza S, Koonin LM, Ajao A. A conceptual framework for allocation of federally stockpiled ventilators during large scale public health emergencies. Health Security. 2016;14(1):1-6. doi: 10.1089/hs.2015.0043 